\section{A Case of Giant Becker's Nevus}

\author{
Müzeyyen Gönül1*, Hasan Benar', Aysun Gökce², Rüstem \\ Şaşmaz' \\ ${ }^{1}$ Diskapi Yildirim Beyazit Education and Research Hospital, Dermatology \\ Department, Diskapi, Ankara, Turkey \\ ${ }^{2}$ Diskapi Yildirim Beyazit Education and Research Hospital, Pathology \\ Department, Diskapi, Ankara, Turkey
}

Keywords: Becker's Nevus; Giant; Hamartoma

\section{Letter}

Sir,

Becker's Nevus (BN) is a cutaneous hamartoma which is characterized by an unilateral, hyperpigmented patch with varying degrees of hypertrichosis [1]. We present a case of giant $\mathrm{BN}$ which is an extremely rare type of $\mathrm{BN}$.

A 16-year-old Turkish female patient was admitted to our clinic with the complaint of a brown lesion located unilaterally on the right side of the body. The lesion had appeared when she was between 3-4 years old. Dermatological examination showed a wide brownish patch with well defined and irregular borders that spreaded from right ankle to ipsilateral middle trunk (Figure 1). Total involvement surface area was estimated to be around $3700 \mathrm{~cm}^{2}$. There was hypertrichosis on the lesion on the lumbar area, and acneiform papules on the thigh (Figure 2). Histopathologic examination of thelesion revealed moderate acanthosis, hyperpigmentation of the basal layer and hyperplasia of the arrector pili muscle (Figure 3). Based on the history, physical examination and histopathological findings of the lesion, the patient was diagnosed as BN. The results of routine laboratory tests such as complete blood count, liver function tests and renal function tests were within normal limits. No pathologic finding was detected in $\mathrm{X}$-ray examination of the legs and abdominal ultrasonography.

Prevalence of $\mathrm{BN}$ is nearly $0.52 \%$ [1]. BN usually has juvenile onset but, rarely, the cases with early onset or congenital cases have been reported [2]. In our case the lesion had started when the patient was 3 years old.

The abnormal androgen receptor activity may play a role in the pathogenesis of BN. Increased androgen receptor density has been shown via immunohistochemical staining, reverse transcriptase

*Corresponding author: Müzeyyen Gönül, Diskapi Yildirim Beyazit Education and Research Hospital, Dermatology Department, Diskapi, Yildizevler Mah, 742. Sok, Aykon Park sitesi, A Blok, No: 3/3, Ankara, Turkey, Tel: 05326667249; E-mail: muzeyyengonul@gmail.com

Citation: Gönül M, Benar H, Gökce A, Şaşmaz R (2015) A Case of Giant Becker's Nevus. J Clin Dermatol Ther 2: 009.

Received: January 02, 2015; Accepted: March 20, 2015; Published: April 03, 2015

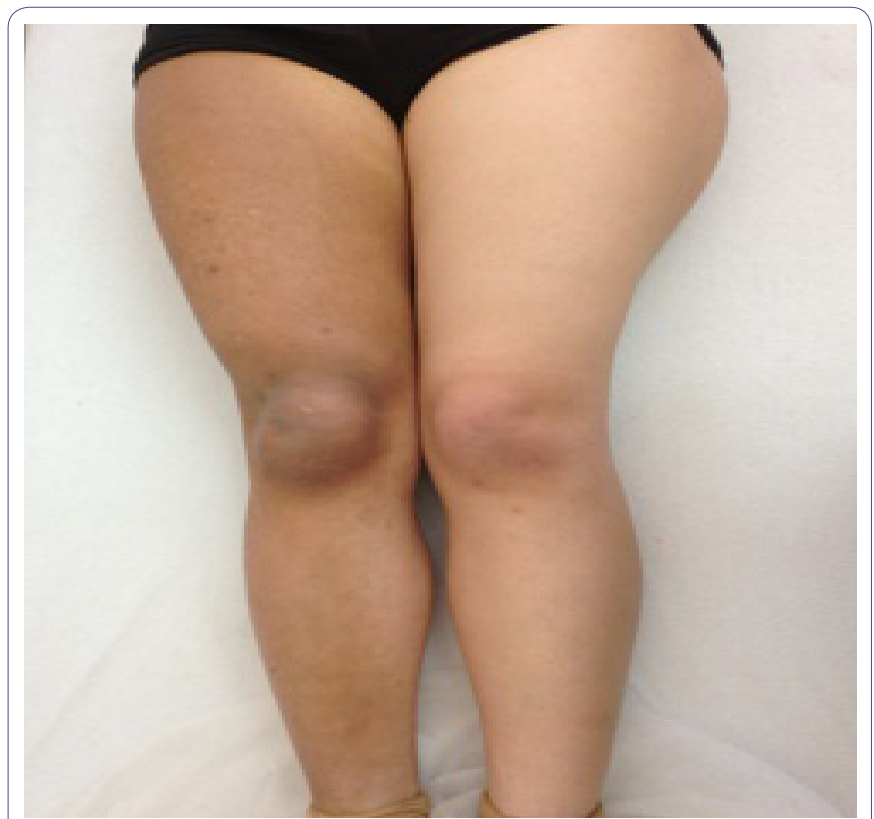

Figure 1: Wide hyperpigmented patch on the right lower extremity.

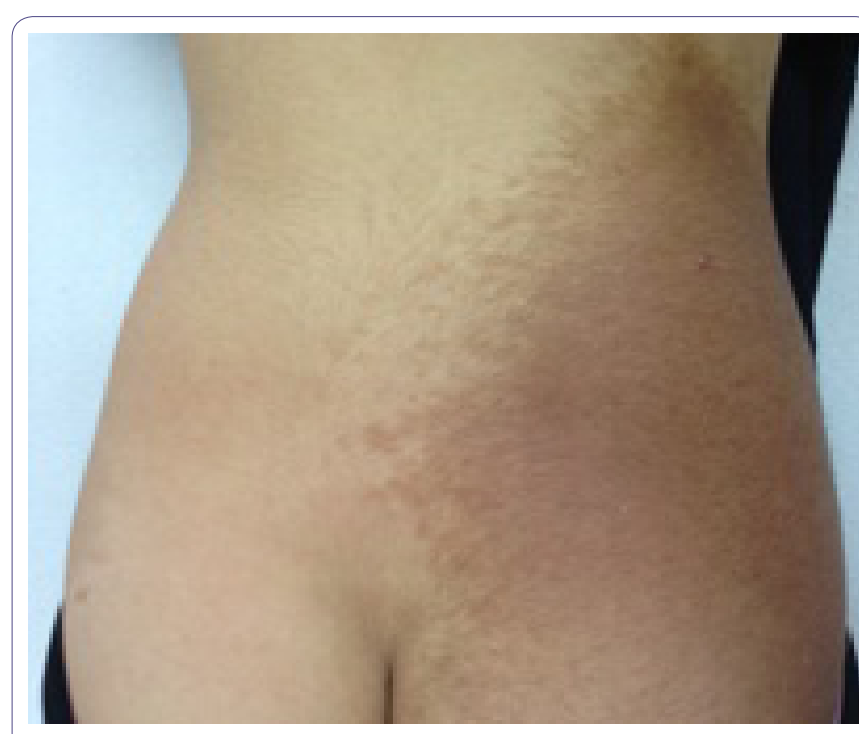

Figure 2: Hypertrichosis over the hyperpigmented patch on the right lumbar area.

polymerase chain reaction of androgen receptor messenger RNA and ligand-binding assays in BN. Hypertrichosis and acneiform lesions on the BN may support the role of abnormal androgen receptor activity [3].

The most frequent localizations of the disease are trunk and legs. Also $\mathrm{BN}$ can be associated with $\mathrm{BN}$ syndrome. $\mathrm{BN}$ syndrome is characterized by $\mathrm{BN}$ with ipsilateral breast hypoplasia or other skin, skeletal and/or muscular disorders [4]. In our case there were no other pathological findings except $\mathrm{BN}$. 


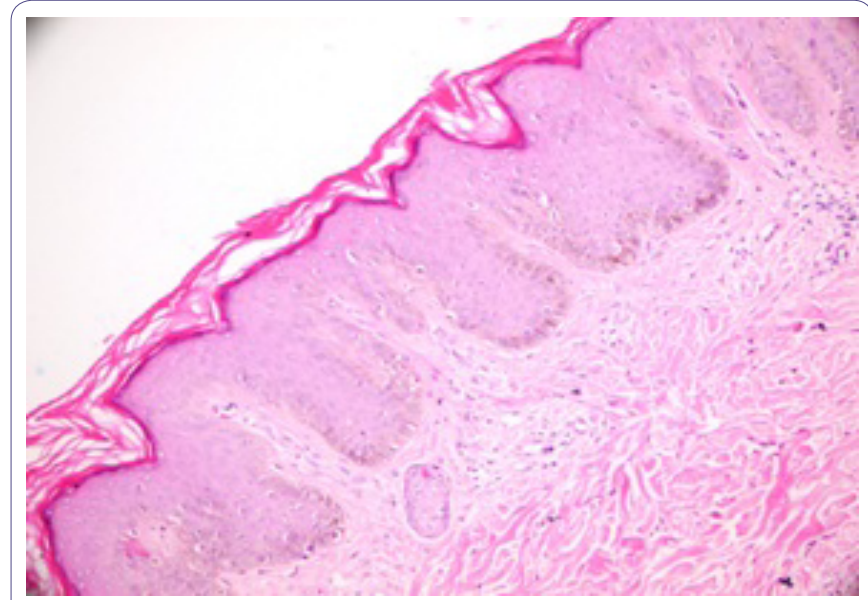

Figure 3: Moderate acanthosis, hyperpigmentation of the basal layer, moderate flattening on rete ridges (H\&E 200).

An average size of $\mathrm{BN}$ is $125 \mathrm{~cm}^{2}$ [5]. There are few reports of giant $\mathrm{BN}$ in the literature. Any threshold size for giant $\mathrm{BN}$ has not been defined previously in literature. Reported cases of giant BN were patients who had usually bilateral torso involvement or a half of trunk [5-7]. BN has covered whole right lower extremity and ipsilateral middle trunk in our case. Khatami et al., reported a giant bilateral Becker's nevus in a 14 year old boy. The age of onset of the disease was when he was 8 years old [4]. Baeta et al., reported a case of giant BN syndrome with breast hypoplasia which had started at the age of 7 [7]. Our case is the $3 \mathrm{rd}$ case of giant $\mathrm{BN}$ and the age of onset of the lesion is earlier than the other reported cases.

Histologic evidences of $\mathrm{BN}$ are acanthosis, hyperkeratosis and hyperpigmentation of the basal layer. The number of melanocytes is generally normal or slightly increased and there are no nevus cells. In some BN cases, hamartomatous smooth muscle fibers may be seen on histopathology but we did not detect it on the histopatological examination of the lesion [7].

BN is only treated for cosmetic reasons. There are limited data about the use of laser for hypertrichosis and hyperpigmentation. Intense pulsed light laser and Erbium:YAG laser may be used for treatment [8]. Laser treatment was recommended to our patient.

We present this case because giant $\mathrm{BN}$ is a very rare type of Becker nevus and we want to emphasize that the diagnosis of $\mathrm{BN}$ should be kept in mind in patients with giant pigmented patches.

\section{References}

1. Ortonne JP, Bahadorian P, Fizpatrick TB et al. (2003) Hypomelanoses and hypermelanosis. In: Freedberg IM, Eisen AZ, Wolff K, Austen KF, Goldsmith LA, et al. (eds.). Fizpatrick's Dermatology in General Medicine. (6th edn), New York, Mc Graw-Hill. Pg: 836-880.

2. Steiner D, Silva FA, Pessanha AC, Bialeski N, Feola C, et al. (2011) Do you know this syndrome? Becker nevus syndrome. An Bras Dermatol 86: 165166.

3. Kim YJ, Han JH, Kang HY, Lee ES, Kim YC (2008) Androgen receptor overexpression in Becker nevus: histopathologic and immunohistochemical analysis. J Cutan Pathol 35: 1121-1126.

4. Khatami A, Seradj MH, Gorouhi F, Firooz A, Dowlati Y (2008) Giant bilateral becker nevus: a rare presentation. Pediatr Dermatol 25: 47-51.

5. Issa G, Blalock TW, Lesher JL (2011) Patient with giant Becker's nevus and epidermal nevus. Dermatol Reports 3: 23.

6. Crone AM, James MP (1997) Giant Becker's naevus with ipsilateral areolar hypoplasia and limb asymmetry. Clin Exp Dermatol 22: 240-241.

7. Baeta IG, Viotti CV, Pereira AC, Costa Júnior SR, Bittencourt FV (2010) Becker's nevus syndrome: case report. An Bras Dermatol 85: 713-716.

8. Trelles MA, Allones I, Moreno-Arias GA, Vélez M (2005) Becker's naevus: a comparative study between erbium: YAG and Q-switched neodymium:YAG; clinical and histopathological findings. Br J Dermatol 152: 308-313. 